IdeAs

Idées d'Amériques

15 | 2020

Eau et gestion de l'eau dans les Amériques

Carrie Teresa, Looking at the Stars: Black Celebrity Journalism in Jim Crow America

Lincoln, Nebraska: University of Nebraska Press, 2019, 249 pages

\title{
Claire Parfait
}

\section{OpenEdition}

\section{Journals}

Édition électronique

URL : http://journals.openedition.org/ideas/7622

DOI : $10.4000 /$ ideas.7622

ISSN : 1950-5701

Éditeur

Institut des Amériques

Référence électronique

Claire Parfait, «Carrie Teresa, Looking at the Stars: Black Celebrity Journalism in Jim Crow America », IdeAs [En ligne], 15 | 2020, mis en ligne le 01 mars 2020, consulté le 24 septembre 2020. URL : http:// journals.openedition.org/ideas/7622 ; DOI : https://doi.org/10.4000/ideas.7622

Ce document a été généré automatiquement le 24 septembre 2020.

\section{c)}

IdeAs - Idées d'Amériques est mis à disposition selon les termes de la licence Creative Commons Attribution - Pas d'Utilisation Commerciale - Pas de Modification 4.0 International. 


\section{Carrie Teresa, Looking at the Stars: Black Celebrity Journalism in Jim Crow America}

Lincoln, Nebraska: University of Nebraska Press, 2019, 249 pages

Claire Parfait

\section{RÉFÉRENCE}

Carrie Teresa, Looking at the Stars: Black Celebrity Journalism in Jim Crow America, Lincoln, Nebraska: University of Nebraska Press, 2019

1 In her introduction to "The Black Press in the United States," Jane Rhodes notes that " The black press is a critical-but often ignored-aspect of African American history and culture." Looking at the Stars: Black Celebrity Journalism in Jim Crow America contributes to addressing this neglect by exploring the ways the black press covered black celebrities over a 40-year period, from 1900 to 1940. In eight chapters, followed by a bibliography and a useful index, Carrie Teresa looks at a diverse set of celebrities, ranging from boxers and athletes to performers, musicians and actors, among others. As Teresa convincingly demonstrates, scholars have so far focused on those black celebrities who crossed the color line and have neglected others who were well-known in their times but did not make it into the mainstream and fell into oblivion. Along the way, Teresa's panorama of black stars therefore resurrects some forgotten figures, like boxer Harry Wills, whose story provides "a lesson in collective amnesia" (p. 194).

2 As Teresa reminds us, at a time of Jim Crow segregation and racial violence, public performance by African Americans was in itself an act of defiance, "challenging the American racial ideology that determined who could rise and who could not" (p. 25). Moreover, the black press was one of the few sites where blacks controlled their representation, and "could obtain and share news about themselves, debate local and national issues, and organize" (p.23). African Americans were systematically 
stereotyped in popular culture, and the black press challenged these demeaning representations and reported on black celebrities, sometimes holding them up as models to follow, sometimes criticizing their private lives as was often the case with boxer Jack Johnson. Whatever the period, the black press expected black stars to act as race representatives and take a stand for the civil rights of African Americans. This explains why the same celebrity could be praised for his/her success and blamed for failing to speak for the community. In spite of these commonalities, the black press did not speak with a single voice, and celebrity reporting unsurprisingly evolved with passing decades. The book traces that evolution and shows how entertainment news reflected the shift from accommodationism to respectability and then militancy.

Chapter 1 explores the growing interest in black celebrities on the part of the African American press, especially after World War I. Chapter 2 pairs heavyweight champion Jack Johnson and blackface comedian Bert Williams to examine their very different backgrounds and trajectories to fame. Teresa shows that however they may have felt about it, the two men were transformed into "exemplary figures carrying on their shoulders the burden of collective representation" (p.34). Both were praised as exemplars of uplift, of the upward economic mobility encouraged by Booker $\mathrm{T}$. Washington among others, but Johnson's sexual indiscretions and flamboyant persona were condemned.

Chapter 3 looks at highbrow culture through the cases of tenor Roland Hayes, British composer Samuel Coleridge-Taylor, and stage actor Charles Gilpin. These international artists provided fitting illustrations of the Talented Tenth that W.E.B. Du Bois envisaged as community leaders. Yet at a time when the "New Negro" emerged, neither Hayes (who was both admired for his international success and blamed for accepting to sing to segregated audiences) nor Gilpin (who allowed himself to be Jim Crowed) fit into the "New Negro" ethos.

5 In chapter 4, Teresa explores the coverage of major performers of the Harlem Renaissance, including actors and jazz musicians such as Cab Calloway, Louis Armstrong, and Duke Ellington. By the Depression years, journalists had abandoned explicit uplift rhetoric, and paid more attention both to gossip and the activism of black stars. Thus Bill Bojangles Robinson was systematically praised for his efforts on behalf of African Americans while Robeson attracted mixed reviews when he failed to get the n-word removed from the script of Eugene O'Neill's Emperor Jones.

Chapter 5 focuses on black female celebrities, whose coverage reflected both misogyny and racism. Journalists, who were predominantly male, paid great attention to women's bodies, subscribing to white notions of beauty, and criticized women like Josephine Baker for violating norms of respectability.

7 The heroes of chapter 6 are sportsmen who both crossed the color line and became national heroes. In the context of the rise of Nazi Germany, track athlete Jesse Owens' medals at the 1936 Olympic Games in Berlin and boxer Joe Louis' victory over German Max Schmeling in 1938 transformed the two men into American rather than African American heroes.

8 Chapter 7 looks at the construction of a "usable past" by commemorations of dead celebrities in the black press. Chapter 8 summarizes the main findings of the book while emphasizing the role of journalists in putting pressure on black celebrities to act as race representatives. 
9 Teresa tells a good story at a brisk pace. As befits a work on celebrities, the book is full of anecdotes and makes for lively, entertaining reading. It is abundantly documented, drawing upon the major black papers and magazines of the time, such as the Pittsburgh Courier, the Baltimore Afro-American, the Philadelphia Tribune, the Chicago Defender, among others. Strangely enough, Marcus Garvey's paper, Negro World, is absent from the study. One could perhaps regret that the author did not provide more information about the individual journalists who appeared in the pages of the various papers. Another regret is the absence (save on a few rare occasions) of readers' reactions to the various articles. Yet the book is well worth reading and will be of interest to the general public, to historians of the media and of the African American press, and students of African American history.

\section{NOTES}

1. Oxford Bibliographies online, 2016, https://www.oxfordbibliographies.com/view/document/ obo-9780190280024/obo-9780190280024-0046.xml

\section{AUTEURS}

\section{CLAIRE PARFAIT}

Claire Parfait est affiliée à la Pléiade, Université Sorbonne Paris Nord 